\title{
PENGARUH CARA BELAJAR DAN PENGGUNAAN MEDIA PEMBELAJARAN \\ TERHADAP PRESTASI BELAJAR AKUNTANSI SISWA KELAS XI IPS SMA NEGERI 2 BANTUL TAHUN AJARAN 2011/2012
}

Oleh:

\author{
Esti Dwi Rohmawati ${ }^{1}$
}

Sukanti ${ }^{2}$

\begin{abstract}
Abstrak
Penelitian ini bertujuan untuk mengetahui: (1) Pengaruh Cara Belajar terhadap Prestasi Belajar Akuntansi Siswa Kelas XI IPS SMA Negeri 2 Bantul Tahun Ajaran 2011/2012; (2) Pengaruh Penggunaan Media Pembelajaran terhadap Prestasi Belajar Akuntansi Siswa Kelas XI IPS SMA Negeri 2 Bantul Tahun Ajaran 2011/2012; (3) Pengaruh Cara Belajar dan Penggunaan Media Pembelajaran secara bersama-sama terhadap Prestasi Belajar Akuntansi Siswa Kelas XI IPS SMA Negeri 2 Bantul Tahun Ajaran 2011/2012.

Penelitian ini merupakan penelitian kausal komparatif, populasi dalam penelitian ini berjumlah 118 siswa kelas XI IPS SMA Negeri 2 Bantul Tahun Ajaran 2011/2012, sampel yang digunakan sejumlah 90 siswa. Teknik pengumpulan data dengan angket dan dokumentasi. Uji coba instrumen dilakukan kepada 28 responden. Uji validitas menggunakan rumus koefisien korelasi Product Moment, sedangkan uji reliabilitas menggunakan rumus Alpha. Uji prasyarat analisis meliputi uji normalitas, uji linieritas dan uji multikolinieritas. Teknik analisis data terdiri dari analisis regresi sederhana dan analisis regresi ganda. Tingkat signifikansi hasil analisis ditentukan 5\%.

Berdasarkan hasil penelitian dapat diperoleh kesimpulan sebagai berikut: (1) Cara Belajar berpengaruh positif dan signifikan terhadap Prestasi Belajar Akuntansi Siswa Kelas XI IPS SMA Negeri 2 Bantul Tahun Ajaran 2011/2012 dengan ditunjukkan harga $\mathrm{r}_{\mathrm{x} 1 \mathrm{y}}$ sebesar 0,$587 ; r^{2}{ }_{x 1 y}$ sebesar 0,$345 ; t_{\text {hitung }}$ lebih besar dari tabel pada taraf signifikansi $5 \%(6,806>$ 1,987) dan persamaan regresi sederhana $Y=0,508 X_{1}+48,107$; (2) Penggunaan Media Pembelajaran berpengaruh positif dan signifikan terhadap Prestasi Belajar Akuntansi Siswa Kelas XI IPS SMA Negeri 2 Bantul Tahun Ajaran 2011/2012 dengan ditunjukkan harga $\mathbf{r}_{\mathrm{x} 2 \mathrm{y}}$ sebesar 0,$500 ; r^{2}$ x2y sebesar 0,$250 ; t_{\text {hitung }}$ lebih besar dari $t_{\text {tabel }}$ pada taraf signifikansi $5 \%(5,420$ $>1,987$ ) dan persamaan regresi sederhana $\mathrm{Y}=0,404 \mathrm{X}_{2}+55,393$; (3) Cara Belajar dan Penggunaan Media Pembelajaran secara bersama-sama berpengaruh positif dan signifikan terhadap Prestasi Belajar Akuntansi Siswa Kelas XI IPS SMA Negeri 2 Bantul Tahun Ajaran 2011/2012 dengan ditunjukkan harga $\mathrm{R}_{\mathrm{y}(1,2)}$ sebesar 0,$635 ; \mathrm{R}_{\mathrm{y}(1,2)}^{2}$ sebesar 0,$404 ; \mathrm{F}_{\text {hitung }}$ lebih besar dari $\mathrm{F}_{\text {tabel }}$ pada taraf signifikansi $5 \%(29,461>3,101)$ dan persamaan regresi ganda $\mathrm{Y}=$ $0,398 X_{1}+0,225 X_{2}+42,190$. Sumbangan Efektif (SE) sebesar 40,4\% dimana sumbangan efektif dari Cara Belajar sebesar 25,97\% dan Penggunaan Media Pembelajaran sebesar $14,43 \%$.
\end{abstract}

\footnotetext{
${ }^{1}$ Alumni Program Studi Pendidikan Akuntansi UNY

2 Dosen Jurusan Pendidikan Akuntansi UNY
} 


\section{A. Pendahuluan}

\section{Latar Belakang Masalah}

Pendidikan mempunyai peranan yang sangat penting dalam mengembangkan kemampuan serta meningkatkan mutu kehidupan bangsa Indonesia. Berkaitan dengan hal tersebut, pemerintah menetapkan sebuah peraturan tentang masalah pendidikan di Indonesia, yang termuat dalam UU No. 20 tahun 2003 tentang Sistem Pendidikan Nasional Pasal 3, bahwa:

Pendidikan Nasional berfungsi mengembangkan kemampuan dan membentuk watak serta peradaban bangsa yang bermartabat dalam rangka mencerdaskan kehidupan bangsa, bertujuan untuk berkembangnya potensi peserta didik agar menjadi manusia yang beriman dan bertaqwa kepada Tuhan Yang Maha Esa, berakhlak mulia, sehat, berilmu, cakap, kreatif, mandiri, dan menjadi warga negara yang demokratis serta bertanggung jawab. (http://www.inherent-dikti.net/files/sisdiknas.pdf, diakses tanggal 15 Desember 2011).

Namun seperti diketahui, bahwa salah satu permasalahan pendidikan yang dihadapi bangsa Indonesia saat ini adalah mengenai rendahnya kualitas pendidikan pada setiap jenjang dan satuan pendidikan. Berbagai upaya telah dilakukan untuk meningkatkan kualitas pendidikan nasional, antara lain melalui berbagai pelatihan dan peningkatan kualifikasi guru, perbaikan sarana dan prasarana, penyempurnaan kurikulum, pengadaan buku dan alat-alat pelajaran serta peningkatan mutu manajemen sekolah. Namun demikian, berbagai indikator kualitas pendidikan belum menunjukkan peningkatan kualitas sesuai dengan harapan.

Kualitas pendidikan pada setiap jenjang dan satuan pendidikan salah satunya dapat dilihat melalui prestasi belajar yang dicapai siswa karena prestasi tersebut menunjukkan sejauh mana tingkat penguasan siswa terhadap mata pelajaran yang telah ditempuh. Untuk jenjang pendidikan tingkat SMA jurusan IPS atau SMK jurusan Akuntansi, kualitas pendidikan salah satunya dapat dilihat dari prestasi belajar akuntansi.

Prestasi belajar akuntansi adalah hasil yang dicapai oleh siswa setelah melakukan kegiatan belajar materi Akuntansi yang dibuktikan melalui hasil tes yang dinyatakan dalam bentuk simbol atau angka. Untuk mendapatkan prestasi belajar akuntansi yang tinggi bukanlah hal yang mudah, tetapi membutuhkan usaha. Oleh karena itu, perlu ditelusuri faktor-faktor yang mempengaruhi prestasi belajar akuntansi. Dengan diketahuinya faktorfaktor yang mempengaruhi prestasi belajar akuntansi diharapkan siswa dapat mencapai prestasi belajar akuntansi yang tinggi.

Secara garis besar, prestasi belajar akuntansi dipengaruhi oleh dua faktor yaitu faktor yang berasal dari dalam diri siswa (internal) dan faktor yang berasal dari luar siswa 
(eksternal). Faktor internal, terdiri dari faktor psikis dan fisik. Faktor psikis meliputi inteligensi, kreativitas, bakat, perhatian, motivasi, disiplin, sikap, mental, cara belajar, keterampilan, sedangkan faktor fisik meliputi jasmani, indera dan syaraf. Faktor eksternal, meliputi rumah, sekolah, termasuk alat atau media pembelajaran, masyarakat dan alam sekitar. Apabila faktor internal dan eksternal tersebut dimaksimalkan fungsinya, maka prestasi belajar akuntansi yang dicapai dapat tinggi.

Cara belajar merupakan salah satu faktor internal yang mempengaruhi prestasi belajar akuntansi siswa. Cara belajar adalah cara atau strategi siswa dalam melakukan kegiatan belajar untuk mencapai prestasi belajar yang diharapkannya. Dalam hal cara belajar tentunya terdapat cara-cara yang baik maupun tidak baik. Banyak siswa gagal atau tidak mendapat hasil yang baik dalam pelajarannya karena tidak mengetahui cara-cara belajar yang efektif dan kebanyakan hanya mencoba menghafal pelajaran. Untuk mencapai prestasi belajar akuntansi yang tinggi diperlukan cara belajar yang baik.

Media pembelajaran merupakan salah satu faktor eksternal yang mempengaruhi prestasi belajar. Penggunaan media pembelajaran adalah cara guru dalam menggunakan alat pengajaran sebagai perantara dalam proses pembelajaran sehingga memudahkan pencapaian tujuan pengajaran. Penggunaan media pembelajaran sangat membantu dalam proses belajar mengajar baik bagi guru maupun para siswa. Media pembelajaran meliputi buku, tape recorder, kaset, video, kamera, film, slide (gambar bingkai), foto, televisi, komputer, dan sebagainya. Penggunaan media pembelajaran membantu guru dalam menyampaikan materi yang mungkin tidak dapat disampaikan hanya dengan lisan, sehingga dapat meningkatkan pemahaman siswa terhadap materi yang disampaikan guru. Penggunaan media pembelajaran haruslah disesuaikan dengan efektivitas dan efisiensi media, kualitas media, sesuai dengan minat, kebutuhan dan kondisi siswa, dan kemampuan guru dalam mengoperasikan. Oleh karena itu, untuk dapat meningkatkan prestasi belajar siswa dibutuhkan penggunaan media pembelajaran yang baik.

Prestasi belajar yang tinggi merupakan dambaan semua pihak, baik pribadi diri siswa, orang tua maupun pihak sekolah, seperti halnya juga di SMA Negeri 2 Bantul. SMA Negeri 2 Bantul merupakan salah satu Sekolah Menengah Atas (SMA) Negeri yang memiliki daya saing cukup tinggi dalam kualitas pendidikan. Sekolah ini beralamat di Jalan R.A Kartini, Trirenggo, Bantul. SMA Negeri 2 Bantul merupakan jenjang sekolah menengah yang sudah menggunakan Kurikulum Tingkat Satuan Pendidikan (KTSP) dalam proses pembelajarannya. 


\section{Jurnal Pendidikan Akuntansi Indonesia, Vol. X, No. 2, Tahun 2012}

Di sekolah ini terdapat dua jurusan yaitu jurusan Ilmu Pengetahuan Alam (IPA) dan Ilmu Pengetahuan Sosial (IPS).

Akuntansi merupakan bagian dari mata pelajaran Ekonomi yang harus diajarkan pada siswa dengan materi sesuai kurikulum yang berlaku. Guru Akuntansi di SMA Negeri 2 Bantul menetapkan Kriteria Ketuntasan Minimal (KKM) yang harus dicapai dalam proses pembelajaran Akuntansi sesuai peraturan kurikulum yang berlaku sebesar 78. Berdasarkan data yang diperoleh peneliti pada saat observasi, diketahui bahwa sebesar 30\% nilai siswa pada Ujian Akhir Semester (UAS) Gasal, dan 25\% pada rata-rata hasil ulangan harian semester gasal belum mencapai KKM.

Berdasarkan observasi diketahui bahwa cara belajar yang dimiliki siswa pada saat mengikuti pelajaran di kelas, cara belajar mandiri, cara mempelajari buku pelajaran, cara belajar kelompok dan cara menghadapi ujian belum menunjukkan cara belajar yang baik. Hal ini menyebabkan prestasi belajar akuntansi siswa belum dapat mencapai KKM.

Permasalahan lain adalah masalah penggunaan media pembelajaran. Penggunaan media pembelajaran oleh guru Akuntansi masih sederhana. Dalam observasi tersebut, media pembelajaran yang digunakan oleh guru adalah modul dan LKS. Penggunaan media tersebut masih perlu ditingkatkan. Selain masalah tersebut, kesadaran akan disiplin siswa masih rendah. Hal tersebut terlihat dari terdapatnya siswa yang masih berada di luar kelas ketika sudah masuk jam pelajaran atau ketika waktu istirahat telah selesai.

Faktor-faktor yang mempengaruhi prestasi belajar akuntansi perlu untuk diteliti karena dengan mengetahui faktor-faktor yang berpengaruh positif maka pihak-pihak yang terkait seperti siswa dan guru dapat meningkatkan faktor-faktor tersebut, sehingga prestasi belajar yang dicapai akan tinggi. Cara belajar dan penggunaan media pembelajaran merupakan faktor-faktor yang dapat mempengaruhi prestasi belajar akuntansi. Oleh karena itu, peneliti tertarik untuk mengadakan penelitian yang berjudul "Pengaruh Cara Belajar dan Penggunaan Media Pembelajaran terhadap Prestasi Belajar Akuntansi Siswa Kelas XI IPS SMA Negeri 2 Bantul Tahun Ajaran 2011/2012”.

\section{Tujuan Penelitian}

1. Untuk mengetahui pengaruh Cara Belajar terhadap Prestasi Belajar Akuntansi Siswa Kelas XI IPS SMA Negeri 2 Bantul Tahun Ajaran 2011/2012. 
2. Untuk mengetahui pengaruh Penggunaan Media Pembelajaran terhadap Prestasi Belajar Akuntansi Siswa Kelas XI IPS SMA Negeri 2 Bantul Tahun Ajaran 2011/2012.

3. Untuk mengetahui pengaruh Cara Belajar dan Penggunaan Media Pembelajaran secara bersama-sama terhadap Prestasi Belajar Akuntansi Siswa Kelas XI IPS SMA Negeri 2 Bantul Tahun Ajaran 2011/2012.

\section{Kajian Pustaka}

\section{a. Prestasi Belajar Akuntansi}

Menurut Nana Sudjana (2002: 22), prestasi belajar adalah kemampuan-kemampuan yang dimiliki siswa setelah ia menerima pengalaman belajarnya. Menurut American Accounting Association (AAA), Akuntansi adalah suatu proses pengidentifikasian, pengukuran, dan pelaporan informasi ekonomi, yang memungkinkan adanya penilaian dan pengambilan keputusan yang jelas dan tegas oleh mereka yang menggunakan informasi keuangan tersebut. Prestasi Belajar Akuntansi adalah hasil yang dicapai oleh siswa setelah melakukan kegiatan belajar materi Akuntansi yang dibuktikan melalui hasil tes yang dinyatakan dalam bentuk simbol atau angka.

Dalyono (2009: 55-60) mengemukakan faktor-faktor yang mempengaruhi prestasi belajar yaitu sebagai berikut:

1) Faktor internal (yang berasal dari dalam diri). Yang termasuk ke dalam faktor internal ini antara lain: kesehatan, inteligensi dan bakat, minat dan motivasi, dan cara belajar.

2) Faktor eksternal (yang berasal dari luar diri). Yang termasuk ke dalam faktor eksternal ini antara lain: keluarga, sekolah, masyarakat, dan lingkungan sekitar.

Ngalim Purwanto (2010: 102-106), menyatakan bahwa berhasil baik atau tidaknya belajar itu tergantung pada bermacam-macam faktor. Adapun faktor-faktor tersebut dapat dibedakan menjadi dua golongan:

1) Faktor yang ada pada diri organisme itu sendiri yang kita sebut faktor individual, antara lain: faktor kematangan/pertumbuhan, kecerdasan, latihan, motivasi dan faktor pribadi.

2) Faktor yang ada di luar individu yang kita sebut faktor sosial, antara lain: faktor keluarga/keadaan rumah tangga, guru dan cara mengajarnya, alat atau media yang dipergunakan dalam belajar-mengajar, lingkungan dan kesempatan yang tersedia, dan motivasi sosial. 


\section{b. Cara Belajar}

Menurut Slameto (2010: 82), cara belajar adalah metode atau jalan yang harus ditempuh untuk mencapai suatu tujuan dalam belajar, yaitu mendapatkan pengetahuan, sikap, kecakapan dan keterampilan. Nana Sudjana (2010: 165-173) mengemukakan beberapa cara belajar yang perlu diperhatikan siswa dalam proses belajar yakni: cara mengikuti pelajaran, cara belajar mandiri, cara belajar kelompok, cara mempelajari buku teks dan cara menghadapi ujian.

\section{c. Penggunaan Media Pembelajaran}

Ibrahim dan Nana Syaodih (2003: 112) mengemukakan bahwa media pembelajaran adalah "segala sesuatu yang dapat digunakan untuk menyalurkan pesan atau isi pelajaran, merangsang pikiran, perasaan, perhatian dan kemampuan siswa, sehingga dapat mendorong proses belajar-mengajar". Penggunaan Media Pembelajaran adalah cara guru dalam menggunakan alat pengajaran sebagai perantara dalam proses pembelajaran sehingga memudahkan pencapaian tujuan pengajaran.

Wina Sanjaya (2009: 171-172) mengemukakan agar media pembelajaran benar-benar digunakan untuk membelajarkan siswa, maka ada sejumlah prinsip yang harus diperhatikan, yaitu: media yang digunakan oleh guru harus sesuai dan diarahkan untuk mencapai tujuan pembelajaran; media yang digunakan harus sesuai dengan materi pembelajaran; media pembelajaran harus sesuai dengan minat, kebutuhan, dan kondisi siswa; media yang akan digunakan harus memperhatikan efektivitas dan efisiensi; media yang digunakan harus sesuai dengan kemampuan guru yang mengoperasikannya.

\section{B. Metode Penelitian}

\section{Desain Penelitian}

Penelitian ini termasuk penelitian ex-post facto. Penelitian ini juga merupakan penelitian kausal komparatif.

\section{Populasi dan Sampel}

Populasi dalam penelitian ini adalah siswa kelas XI IPS SMA Negeri 2 Bantul Tahun Ajaran 2011/2012 berjumlah 118 siswa yang terbagi dalam empat kelas. Teknik pengambilan sampel yang digunakan adalah Proportional Random Sampling. Pengambilan sampel dalam penelitian ini berdasarkan penentuan sampel menurut Isaac dan Michael dengan taraf 
kesalahan 5\% (Sugiyono, 2009: 87). Dengan melihat tabel penentuan jumlah sampel dari populasi sebanyak 118 siswa maka jumlah sampelnya adalah 89 siswa.

\section{Teknik Pengumpulan Data}

a. Angket

Teknik ini digunakan untuk mengumpulkan data mengenai Cara Belajar dan Penggunaan Media Pembelajaran.

b. Dokumentasi

Teknik ini digunakan untuk mengumpulkan data mengenai Prestasi Belajar Akuntansi.

\section{Instrumen Penelitian}

a. Kisi-kisi Instrumen Penelitian

Kisi-kisi instrumen Cara Belajar meliputi cara mengikuti pelajaran, cara belajar mandiri, cara belajar kelompok, cara mempelajari buku teks dan cara menghadapi ujian. Kisikisi instrumen Penggunaan Media Pembelajaran meliputi keefektifan dan efisiensi penggunaan media pembelajaran, kualitas media pembelajaran, kesesuaian dengan minat, kebutuhan dan kondisi siswa, dan kemampuan guru dalam penggunaan media pembelajaran.

b. Uji Coba Instrumen

Tabel 1. Hasil Uji Validitas Instrumen

\begin{tabular}{|c|c|c|c|c|}
\hline Variabel & $\begin{array}{c}\text { Jumlah } \\
\text { butir awal }\end{array}$ & $\begin{array}{c}\text { Jumlah } \\
\text { butir gugur }\end{array}$ & $\begin{array}{c}\text { No. Butir } \\
\text { gugur }\end{array}$ & $\begin{array}{c}\text { Jumlah butir } \\
\text { valid }\end{array}$ \\
\hline $\mathrm{X}_{1}$ & 25 & 3 & $9,15,22$ & 22 \\
\hline $\mathrm{X}_{2}$ & 25 & 4 & $8,10,19,23$ & 21 \\
\hline Jumlah & 50 & 7 & & 43 \\
\hline
\end{tabular}

Tabel 2. Rangkuman Hasil Uji Reliabilitas

\begin{tabular}{|c|l|c|c|}
\hline No. & Instrumen untuk Variabel & $\begin{array}{c}\text { Koefisien alfa } \\
\text { chronbach }\end{array}$ & $\begin{array}{c}\text { Keterangan } \\
\text { Reliabilitas }\end{array}$ \\
\hline 1. & Cara Belajar $\left(\mathrm{X}_{1}\right)$ & 0,866 & Sangat Tinggi \\
\hline 2. & $\begin{array}{l}\text { Penggunaan Media } \\
\text { Pembelajaran }\left(\mathrm{X}_{2}\right)\end{array}$ & 0,927 & Sangat Tinggi \\
\hline
\end{tabular}

\section{Teknik Analisis Data}

a. Uji Prasyarat Analisis

1) Uji Normalitas 
$K_{D}=1,36 \sqrt{\frac{n_{1}+n_{2}}{n_{1} n_{2}}}$

Keterangan :

(Sugiyono, 2010: 159)

$K_{D} \quad=$ Harga Kolmogorof-Smirnov yang dicari

$n_{1} \quad=$ Jumlah sampel yang diobservasi/diperoleh

$n_{2} \quad=$ Jumlah sampel yang diharapkan

2) Uji Linieritas

$F_{\text {reg }}=\frac{R K_{\text {reg }}}{R K_{\text {res }}}$

Keterangan :

$F_{\text {reg }} \quad=$ Harga bilangan $\mathrm{F}$ untuk garis regresi

$R K_{\text {reg }}=$ Rerata kuadrat garis regresi

$R K_{\text {res }}=$ Rerata kuadrat residu

(Sutrisno Hadi, 2004: 14)

3) Uji Multikolinieritas

$r_{x y}=\frac{N \sum X Y-\left(\sum X\right)\left(\sum Y\right)}{\sqrt{\left\{N \sum X^{2}-\left(\sum X\right)^{2}\right\}\left\{N \sum Y^{2}-\left(\sum Y\right)^{2}\right\}}}$

Keterangan:

$r_{x y}=$ koefisien korelasi antara variabel $\mathrm{X}$ dan $\mathrm{Y}$

$N \quad=$ jumlah responden

$\sum X Y \quad=$ jumlah perkalian antara skor variabel $\mathrm{X}_{1}$ dan variabel $\mathrm{X}_{2}$

$\sum X \quad=$ jumlah skor variabel $\mathrm{X}_{1}$

$\sum Y=$ jumlah skor variabel $\mathrm{X}_{2}$

$\left(\sum X^{2}\right) \quad=$ jumlah kuadrat skor variabel $X_{1}$

$\left(\Sigma Y^{2}\right)=$ jumlah kuadrat skor variabel $\mathrm{X}_{2}$

(Suharsimi Arikunto, 2010: 317)

\section{b. Pengujian Hipotesis}

1) Analisis Regresi Sederhana

a) Menghitung koefisien korelasi sederhana antara $X_{1}$ dengan $Y$ dan $X_{2}$ dengan $Y$, dengan rumus sebagai berikut:

$r_{x_{1} y}=\frac{\sum x_{1} y}{\sqrt{\left(\sum x_{1}^{2}\right)\left(\sum y^{2}\right)}}$

$r_{x_{2} y}=\frac{\sum x_{2} y}{\sqrt{\left(\sum x_{2}^{2}\right)\left(\bar{\sum} y^{2}\right)}}$

Keterangan:

$r_{x y} \quad=$ koefisien korelasi antara $\mathrm{X}$ dan $\mathrm{Y}$ 
$\sum x_{1} y \quad=$ jumlah produk antara $\mathrm{X}_{1}$ dan $\mathrm{Y}$

$\sum x_{2} y=$ jumlah produk antara $\mathrm{X}_{2}$ dan $\mathrm{Y}$

$\sum x_{1}^{2}=$ jumlah kuadrat skor prediktor $\mathrm{X}_{1}$

$\sum x_{2}^{2}=$ jumlah kuadrat skor prediktor $\mathrm{X}_{2}$

$\sum y^{2} \quad=$ jumlah kuadrat kriterium $\mathrm{Y}$

b) Menghitung koefisien determinasi $\left(\mathrm{r}^{2}\right)$ antara prediktor $\mathrm{X}_{1}$ dengan $\mathrm{Y}$ dan $\mathrm{X}_{2}$ dengan $\mathrm{Y}$. Rumus sebagai berikut:

$r_{x_{1} y}^{2}=\frac{\mathrm{a}_{1} \sum x_{1} y}{\sum y^{2}}$

$r_{x_{2} y}^{2}=\frac{\mathrm{a}_{2} \sum x_{2} y}{\sum y^{2}}$

\section{Keterangan:}

$r^{2}{ }_{x_{1} y}=$ koefisien determinasi antara $\mathrm{Y}$ dengan $\mathrm{X}_{1}$

$r^{2}{ }_{x_{2} y}=$ koefisien determinasi antara $\mathrm{Y}$ dengan $\mathrm{X}_{2}$

$\mathrm{a}_{1} \quad=$ koefisien prediktor $\mathrm{X}_{1}$

$\mathrm{a}_{2} \quad=$ koefisien prediktor $\mathrm{X}_{2}$

$\sum x_{1} y \quad=$ jumlah produk $\mathrm{X}_{1}$ dengan $\mathrm{Y}$

$\sum x_{2} y=$ jumlah produk $\mathrm{X}_{2}$ dengan $\mathrm{Y}$

$\sum y^{2} \quad=$ jumlah kuadrat kriterium $\mathrm{Y}$

c) Menguji signifikansi dengan uji t

$t=\frac{r \sqrt{n-2}}{\sqrt{1-r^{2}}}$

Keterangan:

$t=$ nilai $t_{\text {hitung }}$

$r \quad=$ koefisien korelasi antara variabel $\mathrm{X}$ dan $\mathrm{Y}$

$n=$ jumlah responden

$r^{2}=$ kuadrat koefisien korelasi antara variabel $\mathrm{X}$ dan $\mathrm{Y}$

d) Membuat persamaan garis regresi linier sederhana

$\mathrm{Y}=\mathrm{a} \mathrm{X}+\mathrm{K}$

Keterangan:

$\mathrm{Y}=$ kriterium

a = bilangan koefisien prediktor

$\mathrm{X}=$ prediktor

$\mathrm{K}$ = bilangan konstan

2) Analisis Regresi Ganda

a) Mencari koefisien korelasi $(R)$ antara $X_{1}$ dan $X_{2}$ dengan kriterium $Y$, dengan rumus:

$R_{y(1,2)}=\sqrt{\frac{\mathrm{a}_{1} \sum x_{1} y+\mathrm{a}_{2} \sum x_{2} y}{\sum y^{2}}}$

Keterangan: 
$R_{y(1,2)} \quad=$ koefisien korelasi antara $\mathrm{Y}$ dengan $\mathrm{X}_{1}$ dan $\mathrm{X}_{2}$

a1 $\quad=$ koefisien prediktor $\mathrm{X}_{1}$

$\mathrm{a}_{2} \quad=$ koefisien prediktor $\mathrm{X}_{2}$

$\sum x_{1} y \quad=$ jumlah produk antara $\mathrm{X}_{1}$ dengan $\mathrm{Y}$

$\sum x_{2} y \quad=$ jumlah produk antara $\mathrm{X}_{2}$ dengan $\mathrm{Y}$

$\sum y^{2} \quad=$ jumlah kuadrat kriterium $\mathrm{Y}$

b) Mencari koefisien determinasi antara $X_{1}$ dan $X_{2}$ dengan kriterium $Y$. Rumus yang digunakan sebagai berikut:

$R^{2}{ }_{y(1,2)}=\frac{\mathrm{a}_{1} \sum x_{1} y+\mathrm{a}_{2} \sum x_{2} y}{\sum y^{2}}$

Keterangan:

$R^{2}{ }_{y(1,2)}=$ koefisien determinasi antara $\mathrm{Y}$ dengan $\mathrm{X}_{1}$ dan $\mathrm{X}_{2}$

$\mathrm{a}_{1} \quad=$ koefisien prediktor $\mathrm{X}_{1}$

$\mathrm{a}_{2} \quad=$ koefisien prediktor $\mathrm{X}_{2}$

$\sum x_{1} y \quad=$ jumlah produk antara $\mathrm{X}_{1}$ dengan $\mathrm{Y}$

$\sum x_{2} y=$ jumlah produk antara $\mathrm{X}_{2}$ dengan $\mathrm{Y}$

$\sum y^{2} \quad=$ jumlah kuadrat kriterium $\mathrm{Y}$

c) Menguji keberartian regresi ganda dengan uji $\mathrm{F}$, dengan rumus:

$F_{\text {reg }}=\frac{R^{2}(N-m-1)}{m\left(1-R^{2}\right)}$

Keterangan:

$F=$ harga $\mathrm{F}$ garis regresi

$N=$ cacah kasus

$M=$ cacah prediktor

$R=$ koefisien korelasi antara kriterium dengan prediktor

d) Membuat persamaan garis regresi dua prediktor dengan rumus:

$Y=\mathrm{a}_{1} X_{1}+\mathrm{a}_{2} X_{2}+\mathrm{K}$

Keterangan :

$Y=$ kriterium

$\mathrm{a}_{1}, \mathrm{a}_{2}=$ koefisien prediktor 1 , koefisien prediktor 2

$X_{1}, X_{2}=$ prediktor 1 , prediktor 2

$\mathrm{K}=$ konstanta

e) Mencari besarnya sumbangan setiap variabel prediktor terhadap kriterium dengan menggunakan rumus:

Sumbangan Relatif (SR)

$S R \%=\frac{\mathrm{a} \sum X Y}{J K_{\text {reg }}} \times 100 \%$

$I K_{\text {reg }}=\mathrm{a}_{1} \sum X_{1} Y+\mathrm{a}_{2} \sum X_{2} Y$

Keterangan: 


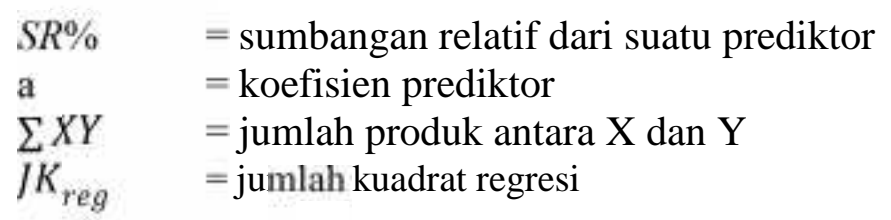

\section{Sumbangan Efektif (SE)}

$S E \%=S R \% \times R^{2}$

Keterangan:

$S E \% \quad=$ sumbangan efektif dari suatu prediktor

$S R \%=$ sumbangan relatif dari suatu prediktor

$R^{2} \quad=$ koefisien determinasi

\section{Hasil Penelitian dan Pembahasan}

\section{Statistik Deskriptif}

\section{a. Prestasi Belajar Akuntansi}

Data Prestasi Belajar Akuntansi diperoleh melalui dokumentasi nilai ulangan harian, nilai tugas, dan nilai Ujian Tengah Semester (UTS) genap. Nilai rerata dari ketiga nilai tersebut menunjukkan bahwa nilai tertinggi adalah 94 dari nilai tertinggi yang mungkin dicapai 100, dan nilai terendah adalah 60. Berdasarkan data variabel Prestasi Belajar Akuntansi yang diolah menggunakan SPSS Statistic 18.0 for Windows diperoleh Mean (M) sebesar 78,93; Median (Me) sebesar 80,00; Modus (Mo) sebesar 80 dan Standar Deviasi (SD) sebesar 8,139 .

\section{b. Cara Belajar}

Data Variabel Cara Belajar diperoleh dari angket yang terdiri dari 22 butir pernyataan dengan jumlah responden 90 siswa. Berdasarkan data penelitian yang diolah menggunakan bantuan program SPSS Statistic 18.0 for Windows, diketahui bahwa variabel Cara Belajar memiliki skor tertinggi 78 dari skor tertinggi yang mungkin dicapai $(4 \times 22)=88$, dan skor

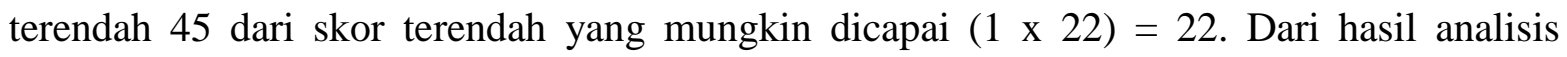
diperoleh Mean (M) sebesar 60,68; Median (Me) sebesar 62,50; Modus (Mo) sebesar 49; dan Standar Deviasi (SD) sebesar 9,408.

\section{c. Penggunaan Media Pembelajaran}

Data variabel Penggunaan Media Pembelajaran diperoleh dari angket yang terdiri dari 21 butir pernyataan dengan jumlah responden 90 siswa. Berdasarkan data penelitian yang diolah menggunakan bantuan program SPSS Statistic 18.0 for Windows, menunjukkan bahwa variabel Penggunaan Media Pembelajaran memiliki skor tertinggi 74 dari skor tertinggi yang 
Jurnal Pendidikan Akuntansi Indonesia, Vol. X, No. 2, Tahun 2012

Esti Dwi Rohmawati \& Sukanti

Halaman $153-171$

mungkin dicapai $(4 \times 21)=84$, dan skor terendah 41 dari skor terendah yang mungkin dicapai $(1 \times 21)=21$. Dari hasil analisis diperoleh Mean $(\mathrm{M})$ sebesar 58,23; Median (Me) sebesar 60,00; Modus (Mo) sebesar 64; dan Standar Deviasi (SD) sebesar 10,074.

\section{Hasil Prasyarat Analisis}

a. Uji Normalitas

Tabel 3. Ringkasan Hasil Uji Normalitas

\begin{tabular}{|c|l|c|c|c|c|}
\hline No. & \multicolumn{1}{|c|}{ Variabel } & $\begin{array}{c}\mathbf{K}_{\mathbf{D}} \\
\text { hitung }\end{array}$ & $\mathbf{K}_{\mathbf{D}}$ tabel & $\mathbf{P}$ & $\mathbf{K e t .}$ \\
\hline 1. & Cara Belajar & 0,137 & 0,141 & 0,067 & $\begin{array}{c}\text { Distribusi } \\
\text { normal }\end{array}$ \\
\hline 2. & $\begin{array}{l}\text { Penggunaan Media } \\
\text { Pembelajaran }\end{array}$ & 0,103 & 0,141 & 0,296 & $\begin{array}{c}\text { Distribusi } \\
\text { normal }\end{array}$ \\
\hline 3. & $\begin{array}{l}\text { Prestasi Belajar } \\
\text { Akuntansi }\end{array}$ & 0,080 & 0,141 & 0,608 & $\begin{array}{c}\text { Distribusi } \\
\text { normal }\end{array}$ \\
\hline
\end{tabular}

\section{b. Uji Linieritas}

Tabel 4. Ringkasan Hasil Uji Linieritas

\begin{tabular}{|c|c|c|c|c|c|c|}
\hline No. & Model & df & Fhitung & F $_{\text {tabel }}$ & $\mathbf{P}$ & Kesimpulan \\
\hline 1. & $\mathrm{X}_{1}-\mathrm{Y}$ & $30 ; 58$ & 0,966 & 1,656 & 0,530 & Linier \\
\hline 2. & $\mathrm{X}_{2}-\mathrm{Y}$ & $30 ; 58$ & 0,707 & 1,656 & 0,848 & Linier \\
\hline
\end{tabular}

\section{c. Uji Multikolinieritas}

Tabel 5. Ringkasan Hasil Uji Multikolinieritas

\begin{tabular}{|l|c|c|c|}
\hline \multicolumn{1}{|c|}{ Variabel } & $\mathbf{X}_{\mathbf{1}}$ & $\mathbf{X}_{\mathbf{2}}$ & Kesimpulan \\
\hline Cara Belajar & 1 & 0,492 & $\begin{array}{c}\text { Tidak terjadi } \\
\text { multikolinieritas }\end{array}$ \\
\cline { 1 - 2 } $\begin{array}{l}\text { Penggunaan Media } \\
\text { Pembelajaran }\end{array}$ & 0,492 & 1 & \\
\hline
\end{tabular}

\section{Hasil Pengujian Hipotesis}

a. Pengujian Hipotesis Pertama

Tabel 6. Ringkasan Hasil Uji Regresi Sederhana ( $\left.\mathrm{X}_{1}-\mathrm{Y}\right)$

\begin{tabular}{|c|c|c|c|c|c|c|c|}
\hline Variabel & rhitung & $\mathbf{r}^{2}$ & thitung & t tabel & $\begin{array}{c}\text { Koefs. } \\
\text { variabel }\end{array}$ & Konst. & Ket. \\
\hline $\mathrm{X}_{1}-\mathrm{Y}$ & 0,587 & 0,345 & 6,806 & 1,987 & 0,508 & 48,107 & $\begin{array}{c}\text { Positif dan } \\
\text { signifikan }\end{array}$ \\
\hline
\end{tabular}


Jurnal Pendidikan Akuntansi Indonesia, Vol. X, No. 2, Tahun 2012

Esti Dwi Rohmawati \& Sukanti

Halaman $153-171$

\section{b. Pengujian Hipotesis Kedua}

Tabel 7. Ringkasan Hasil Uji Regresi Sederhana $\left(\mathrm{X}_{2}-\mathrm{Y}\right)$

\begin{tabular}{|c|c|c|c|c|c|c|c|}
\hline Variabel & $\mathbf{r}_{\text {hitung }}$ & $\mathbf{r}^{\mathbf{2}}$ & $\mathbf{t}_{\text {hitung }}$ & $\mathbf{t}_{\text {tabel }}$ & $\begin{array}{c}\text { Koefs. } \\
\text { variabel }\end{array}$ & Konst. & Ket. \\
\hline $\mathrm{X}_{2}-\mathrm{Y}$ & 0,500 & 0,250 & 5,420 & 1,987 & 0,404 & 55,393 & $\begin{array}{c}\text { Positif dan } \\
\text { signifikan }\end{array}$ \\
\hline
\end{tabular}

\section{c. Pengujian Hipotesis Ketiga}

Tabel 8. Ringkasan Hasil Analisis Regresi Ganda

\begin{tabular}{|c|c|c|c|c|c|c|c|c|}
\hline \multicolumn{2}{|c|}{ Variabel } & $\mathbf{R}_{\mathbf{y}(\mathbf{1}, \mathbf{2})}$ & $\mathbf{R}_{\mathbf{y}(\mathbf{1}, \mathbf{2})}$ & $\mathbf{F}_{\text {hitung }}$ & $\mathbf{F}_{\text {tabel }}$ & $\begin{array}{c}\text { Koefs. } \\
\text { variabel }\end{array}$ & Konst. & Ket. \\
\hline $\mathrm{X}_{1}$ & $\mathrm{Y}$ & 0,635 & 0,404 & $\begin{array}{c}29,46 \\
1\end{array}$ & 3,101 & 0,389 & 42,190 & $\begin{array}{c}\text { Positif dan } \\
\text { signifikan }\end{array}$ \\
\hline
\end{tabular}

\section{Pembahasan}

\section{a. Pengaruh Cara Belajar terhadap Prestasi Belajar Akuntansi Siswa Kelas XI IPS SMA Negeri 2 Bantul Tahun Ajaran 2011/2012.}

Hasil penelitian ini menunjukkan bahwa Cara Belajar berpengaruh positif dan signifikan terhadap Prestasi Belajar Akuntansi. Dari hasil analisis regresi sederhana (satu prediktor) diperoleh harga koefisien korelasi $\left(\mathrm{r}_{\mathrm{x} 1 \mathrm{y}}\right)$ sebesar 0,587 menunjukkan hasil positif yang berarti Cara Belajar berpengaruh positif terhadap Prestasi Belajar Akuntansi. Semakin baik Cara Belajar maka semakin tinggi Prestasi Belajar Akuntansi. Sedangkan harga koefisien determinasi $\left(\mathrm{r}^{2}{ }_{\mathrm{x} 1 \mathrm{y}}\right)$ sebesar 0,345 menunjukkan bahwa Cara Belajar memiliki kontribusi pengaruh terhadap Prestasi Belajar Akuntansi sebesar 34,5\%. Setelah dilakukan uji $\mathrm{t}$ diperoleh harga thitung sebesar 6,806 lebih besar dari tabel pada taraf signifikansi 5\% sebesar 1,987 atau nilai signifikansi sebesar $0,000<\alpha=0,05$ yang berarti pengaruh Cara Belajar terhadap Prestasi Belajar Akuntansi adalah signifikan. Dengan demikian dapat disimpulkan bahwa Cara Belajar berpengaruh positif dan signifikan terhadap Prestasi Belajar Akuntansi.

Berdasarkan hasil perhitungan diperoleh harga koefisien variabel Cara Belajar sebesar 0,508 dan bilangan konstanta sebesar 48,107 sehingga model persamaan regresi yang terbentuk adalah $Y=0,508 X_{1}+48,107$. Hal ini berarti apabila Cara Belajar ditingkatkan satu satuan maka nilai Prestasi Belajar Akuntansi akan meningkat sebesar 0,508.

Hasil penelitian ini diperkuat dengan kajian teori dan penelitian yang relevan. Berdasarkan teori yang dikemukakan oleh Dalyono (2009: 57), cara belajar merupakan salah satu faktor internal yang mempengaruhi prestasi belajar siswa. Hasil penelitian ini juga selaras dengan penelitian yang dilakukan oleh Ani Suryaningsih (2010) yang menyatakan 
terdapat pengaruh positif dan signifikan Cara Belajar terhadap Prestasi Belajar Akuntansi Siswa Kelas XI IPS SMA Negeri 1 Srandakan Tahun Ajaran 2009/2010 dengan ditunjukkan koefisien korelasi (r) sebesar 0,519; koefisien determinasi $\left(r^{2}\right)$ sebesar 0,269 dan $t_{\text {hitung }}$ sebesar 5,003 lebih besar dari $t_{\text {tabel }}$ pada taraf signifikansi 5\% sebesar 2,000. Persamaan regresi sederhana $\mathrm{Y}=53,240+0,399 \mathrm{X}$, Sumbangan Efektif (SE) sebesar 23,23.

\section{b. Pengaruh Penggunaan Media Pembelajaran terhadap Prestasi Belajar Akuntansi Siswa Kelas XI IPS SMA Negeri 2 Bantul Tahun Ajaran 2011/2012.}

Hasil penelitian ini menunjukkan bahwa Penggunaan Media Pembelajaran berpengaruh positif dan signifikan terhadap Prestasi Belajar Akuntansi. Dari hasil analisis menggunakan regresi sederhana (satu prediktor) diperoleh harga koefisien korelasi $\left(\mathrm{r}_{\mathrm{x} 2 \mathrm{y}}\right)$ sebesar 0,500 menunjukkan hasil positif yang berarti Penggunaan Media Pembelajaran berpengaruh positif terhadap Prestasi Belajar Akuntansi. Semakin baik penggunaan media pembelajaran maka semakin tinggi Prestasi Belajar Akuntansi. Harga koefisien determinasi $\left(r^{2}\right.$ xy) sebesar 0,250 menunjukkan bahwa Penggunaan Media Pembelajaran memiliki kontribusi pengaruh terhadap Prestasi Belajar Akuntansi sebesar 25\%. Setelah dilakukan uji t diperoleh harga $t_{\text {hitung }}$ sebesar 5,420 lebih besar dari $t_{\text {tabel }}$ pada taraf signifikansi 5\% sebesar 1,987 atau nilai signifikansi $0,000<\alpha=0,05$ yang berarti pengaruh Penggunaan Media Pembelajaran terhadap Prestasi Belajar Akuntansi adalah signifikan. Dengan demikian dapat disimpulkan bahwa Penggunaan Media Pembelajaran berpengaruh positif dan signifikan terhadap Prestasi Belajar Akuntansi.

Berdasarkan hasil perhitungan diperoleh harga koefisien variabel Penggunaan Media Pembelajaran sebesar 0,404 dan bilangan konstanta sebesar 55,393 sehingga model persamaan regresi yang terbentuk adalah $\mathrm{Y}=0,404 \mathrm{X}_{2}+55,393$. Hal ini berarti apabila Penggunaan Media Pembelajaran ditingkatkan satu satuan maka nilai Prestasi Belajar Akuntansi akan meningkat sebesar 0,404.

Hasil penelitian ini diperkuat dengan kajian teori dan penelitian yang relevan. Berdasarkan teori yang dikemukakan oleh Ngalim Purwanto (2010: 105), penggunaan media pembelajaran merupakan salah satu faktor yang ada di luar individu yang mempengaruhi prestasi belajar siswa. Hasil penelitian ini juga selaras dengan penelitian yang dilakukan Aprilia Widyastuti (2008) yang menyatakan terdapat pengaruh positif dan signifikan Penggunaan Media Pembelajaran terhadap Prestasi Belajar Akuntansi Siswa Kelas XI IPS SMA Negeri 1 Pengasih Tahun Ajaran 2007/2008 dengan ditunjukkan koefisien korelasi (r) 
sebesar 0,221; koefisien determinasi $\left(r^{2}\right)$ sebesar 0,049 dan $t_{\text {hitung }}$ sebesar 8,156 lebih besar $\mathrm{t}_{\text {tabel }}$ sebesar 1,671 pada taraf signifikansi 5\%.

\section{c. Pengaruh Cara Belajar dan Penggunaan Media Pembelajaran secara bersama-sama terhadap Prestasi Belajar Akuntansi Siswa Kelas XI IPS SMA Negeri 2 Bantul Tahun Ajaran 2011/2012.}

Hasil penelitian ini menunjukkan bahwa Cara Belajar dan Penggunaan Media Pembelajaran secara bersama-sama berpengaruh positif dan signifikan terhadap Prestasi Belajar Akuntansi. Dari hasil analisis regresi ganda (dua prediktor) diperoleh harga koefisien korelasi $\mathrm{R}_{\mathrm{y}(1,2)}$ sebesar 0,635 menunjukkan hasil positif yang berarti Cara Belajar dan Penggunaan Media Pembelajaran secara bersama-sama berpengaruh positif terhadap Prestasi Belajar Akuntansi. Semakin baik Cara Belajar dan Penggunaan Media Pembelajaran maka Prestasi Belajar Akuntansi semakin tinggi. Harga koefisien determinasi $R^{2} y(1,2)$ sebesar 0,404 mempunyai arti bahwa Cara Belajar dan Penggunaan Media Pembelajaran secara bersamasama memiliki kontribusi pengaruh terhadap Prestasi Belajar Akuntansi sebesar 40,4\%. Setelah dilakukan uji $\mathrm{F}$ diperoleh harga $\mathrm{F}_{\text {hitung }}$ sebesar 29,461 lebih besar dari $\mathrm{F}_{\text {tabel }}$ pada taraf signifikansi $5 \%$ sebesar 3,101 atau nilai signifikansi $\mathrm{F}=0,000<$ sig. $=0,05$ yang berarti pengaruh variabel Cara Belajar dan Penggunaan Media Pembelajaran terhadap Prestasi Belajar Akuntansi adalah signifikan.

Berdasarkan hasil perhitungan diperoleh harga koefisien variabel Cara Belajar sebesar 0,389 dan harga koefisien variabel Penggunaan Media Pembelajaran sebesar 0,225 serta bilangan konstanta sebesar 42,190 sehingga model persamaan regresi yang terbentuk adalah $\mathrm{Y}=0,389 \mathrm{X}_{1}+0,225 \mathrm{X}_{2}+42,190$. Persamaan tersebut menunjukkan nilai koefisien variabel $\mathrm{X}_{1}$ sebesar 0,389 yang berarti apabila Cara Belajar ditingkatkan satu satuan maka nilai Prestasi Belajar Akuntansi akan meningkat sebesar 0,389 dengan asumsi Penggunaan Media Pembelajaran tetap. Nilai koefisien variabel $\mathrm{X}_{2}$ sebesar 0,225 yang berarti apabila Penggunaan Media Pembelajaran ditingkatkan satu satuan maka nilai Prestasi Belajar Akuntansi akan meningkat sebesar 0,225 dengan asumsi Cara Belajar tetap. Dengan demikian dapat disimpulkan bahwa Cara Belajar dan Penggunaan Media Pembelajaran secara bersama-sama berpengaruh positif dan signifikan terhadap Prestasi Belajar Akuntansi.

Nilai sumbangan relatif variabel Cara Belajar sebesar 64,3\% dan variabel Penggunaan Media Pembelajaran sebesar 35,7\%. Sedangkan nilai sumbangan efektif yang diberikan variabel Cara Belajar sebesar 25,97\% dan Penggunaan Media Pembelajaran sebesar 14,43\%. 
Secara bersama-sama variabel Cara Belajar dan Penggunaan Media Pembelajaran memberikan sumbangan efektif sebesar 40,4\% terhadap Prestasi Belajar Akuntansi, sedangkan sebesar 59,6\% diberikan oleh variabel-variabel lain yang tidak diteliti dalam penelitian ini.

Hasil penelitian ini diperkuat dengan kajian teori dan penelitian yang relevan. Berdasarkan teori yang dikemukakan oleh Dalyono (2009: 57) dan Ngalim Purwanto (2010: 105) diketahui bahwa cara belajar dan penggunaan media pembelajaran termasuk ke dalam faktor-faktor yang mempengaruhi prestasi belajar. Hasil penelitian ini juga didukung oleh hasil penelitian Ani Suryaningsih (2010) dan Aprilia Widyastuti (2008). Hasil penelitian Ani Suryaningsih (2010) menyatakan bahwa terdapat pengaruh positif dan signifikan Cara Belajar terhadap Prestasi Belajar Akuntansi dengan ditunjukkan koefisien korelasi (r) sebesar 0,519; koefisien determinasi $\left(r^{2}\right)$ sebesar 0,269; $t_{\text {hitung }}$ sebesar 5,003 lebih besar dari $t_{\text {tabel }}$ pada taraf signifikansi 5\% sebesar 2,00; persamaan regresi sederhana $\mathrm{Y}=53,240+0,3999 \mathrm{X}$; Sumbangan Efektif (SE) sebesar 23.23\%. Hasil penelitian Aprilia Widyastuti (2008) menyatakan bahwa terdapat pengaruh positif dan signifikan Penggunaan Media Pembelajaran terhadap Prestasi Belajar Akuntansi dengan ditunjukkan koefisien korelasi (r) sebesar 0,221, koefisien determinasi $\left(r^{2}\right)$ sebesar 0,049 dan $t_{\text {hitung }}$ sebesar 8,156 lebih besar dari $t_{\text {tabel }}$ sebesar 1,671 pada taraf signifikansi $5 \%$.

\section{Penutup}

\section{Kesimpulan}

a. Cara Belajar berpengaruh positif dan signifikan terhadap Prestasi Belajar Akuntansi Siswa Kelas XI IPS SMA Negeri 2 Bantul Tahun Ajaran 2011/2012. Hal tersebut ditunjukkan dengan harga koefisien korelasi $r_{x 1 y}$ sebesar 0,$587 ; r^{2}{ }_{x 1 y}$ sebesar 0,345 dan $t_{\text {hitung }}$ sebesar 6,806 lebih besar dari $t_{\text {tabel }}$ pada taraf signifikansi 5\% sebesar 1,987. Persamaan regresi sederhana $\mathrm{Y}=0,508 \mathrm{X}_{1}+48,107$.

b. Penggunaan Media Pembelajaran berpengaruh positif dan signifikan terhadap Prestasi Belajar Akuntansi Siswa Kelas XI IPS SMA Negeri 2 Bantul Tahun Ajaran 2011/2012. Hal tersebut ditunjukkan dengan harga koefisien korelasi $r_{x 2 y}$ sebesar 0,$500 ; r^{2}{ }_{x 2 y}$ sebesar 0,250 dan $t_{\text {hitung }}$ sebesar 5,420 lebih besar dari $t_{\text {tabel }}$ pada taraf signifikansi $5 \%$ sebesar 1,987. Persamaan regresi sederhana $\mathrm{Y}=0,404 \mathrm{X}_{2}+55,398$.

c. Cara Belajar dan Penggunaan Media Pembelajaran secara bersama-sama berpengaruh positif dan signifikan terhadap Prestasi Belajar Akuntansi Siswa Kelas XI IPS SMA 
Negeri 2 Bantul Tahun Ajaran 2011/2012. Hal tersebut ditunjukkan dengan harga $R_{y(1,2)}$ sebesar 0,635; $\mathrm{R}_{\mathrm{y}(1,2)}$ sebesar 0,404 dan $\mathrm{F}_{\text {hitung }}$ sebesar 29,461 lebih besar dari $\mathrm{F}_{\text {tabel }}$ pada taraf signifikansi 5\% sebesar 3,101. Persamaan regresi ganda $Y=0,389 X_{1}+0,225 X_{2}+$ 42,190. Sumbangan Efektif (SE) yang diberikan kedua variabel terhadap Prestasi Belajar Akuntansi sebesar 40,4\% dimana SE dari Cara Belajar sebesar 25,97\% dan Penggunaan Media Pembelajaran sebesar 14,43\%.

\section{Saran}

a. Bagi Siswa

Siswa hendaknya menyadari bahwa belajar adalah sangat penting dalam pendidikan. Tanpa belajar akan sulit untuk mencapai prestasi yang baik. Untuk mencapai Prestasi Belajar Akuntansi yang tinggi maka siswa harus menerapkan cara belajar yang baik, yaitu dengan membuat jadwal belajar yang baik di rumah dan secara disiplin menepati jadwal yang telah dibuat, selain itu penting bagi siswa dalam meningkatkan kedisiplinan belajar kelompok secara baik. Dengan belajar kelompok siswa akan saling bertukar pengetahuan dan hasil yang dicapai bisa lebih baik. Cara belajar yang dimiliki oleh siswa turut mendukung prestasi belajar yang dicapainya.

\section{b. Bagi Guru}

Ketika mengajar Akuntansi, guru hendaknya menggunakan media pembelajaran secara tepat, media pembelajaran yang menarik, sehingga siswa tidak merasa bosan dalam mengikuti pelajaran. Dengan penggunaan media pembelajaran yang baik, siswa akan lebih mudah dalam menguasai materi pelajaran. Hal tersebut sangat membantu siswa dalam meningkatkan prestasi belajar akuntansi. Selain itu, guru juga dapat memotivasi siswa untuk rajin belajar kelompok sehingga pengetahuan siswa bertambah.

\section{c. Bagi Peneliti Selanjutnya}

Penelitian ini mengungkap Prestasi Belajar Akuntansi yang melibatkan dua variabel yaitu variabel Cara Belajar dan Penggunaan Media Pembelajaran. Kedua variabel ini menjelaskan variansi Prestasi Belajar Akuntansi sebesar 40,4\%. Oleh karena itu perlu adanya penelitian lebih lanjut tentang faktor-faktor yang diduga memiliki pengaruh terhadap prestasi belajar akuntansi karena dalam teori disebutkan bahwa banyak faktor-faktor yang ada kaitannya dengan pencapaian prestasi belajar. 


\section{E. Daftar Pustaka}

Alam S. (2007). Ekonomi untuk SMA dan MA Kelas XI. Jakarta: Erlangga.

Ani Suryaningsih. (2010). "Pengaruh Lingkungan Keluarga dan Cara Belajar terhadap Prestasi Belajar Akuntansi Siswa Kelas XI IPS SMA Negeri 1 Srandakan Tahun Ajaran 2009/2010”. Skripsi. Yogyakarta: FISE UNY.

Aprilia Widyastuti. (2008). "Pengaruh Persepsi Siswa tentang Metode Mengajar Guru, Penggunaan Media Pembelajaran dan Partisipasi Siswa di Kelas terhadap Prestasi Belajar Akuntansi Siswa Kelas XI IPS SMA Negeri 1 Pengasih Tahun Ajaran 2007/2008”. Skripsi. Yogyakarta: FISE UNY

Asrori Ardiansyah. (2011). Pengertian Cara Belajar. Diambil dari: http://kabarpendidikan.blogspot.com/2011/05/cara-belajar.html, diakses 31 Januari 2012.

Atin Puji Astutik. (2011). "Pengaruh Penggunaan Media Pembelajaran dan Motivasi Belajar terhadap Prestasi Belajar Akuntansi Siswa Kelas XI Program IPS SMA Negeri 1 Sewon Bantul Tahun Ajaran 2010/2011”. Skripsi. Yogyakarta: FISE UNY

Dalyono. (2009). Psikologi Pendidikan. Jakarta: PT Rineka Cipta.

Danang Sunyoto. (2007). Analisis Regresi dan Korelasi Bivariat. Yogyakarta: Amara Books.

Daryanto. (2009). Panduan Proses Pembelajaran Kreatif dan Inovatif. Jakarta: AV Publisher.

Depdiknas. (2003). Undang-undang Sistem Pendidikan Nasional. Diambil dari: http://www.inherent-dikti.net/files/sisdiknas.pdf, diakses 15 Desember 2011.

Ganis. (2010). Masalah Pendidikan di Indonesia. Diambil dari: http://ganis.student.umm.ac.id/2010/01/26/masalah-pendidikan-di-indonesia, diakses 15 Desember 2011.

Haryono Jusup. (2005). Dasar-dasar Akuntansi Jilid I. Yogyakarta: STIE YKPN.

Ibrahim dan Nana Syaodih S. (2003). Perencanaan Pengajaran. Jakarta: PT Rineka Cipta.

Martinis Yamin. (2007). Kiat Membelajarkan Siswa. Jakarta: Gaung Persada Press.

Muhibbin Syah. (2010). Psikologi Pendidikan dengan Pendekatan Baru. Bandung: PT Remaja Rosdakarya.

Nana Syaodih Sukmadinata. (2009). Landasan Psikologi Proses Pendidikan. Bandung: PT Remaja Rosdakarya.

Nana Sudjana. (2002). Penilaian Hasil Belajar Mengajar. Bandung: PT Remaja Rosdakarya. Algensindo.

(2010). Dasar-dasar Proses Belajar Mengajar. Bandung: Sinar Baru 
Ngalim Purwanto. (2010). Psikologi Pendidikan. Bandung: PT Remaja Rosdakarya.

Nur Hanifah. (2009). "Pengaruh Lingkungan Sekolah dan Cara Belajar Siswa terhadap Prestasi Belajar Akuntansi Siswa Kelas XI IPS di SMA Negeri 1 Ngemplak Tahun Ajaran 2008/2009”. Skripsi. Yogyakarta: FISE UNY.

Saifuddin Azwar. (2009). Penyusunan Skala Psikologi. Yogyakarta: Pustaka Pelajar.

Slameto. (2010). Belajar dan Faktor-faktor yang Mempengaruhinya. Jakarta: PT Rineka Cipta.

Sugihartono, dkk. (2007). Psikologi Pendidikan. Yogyakarta: UNY Press.

Sugiyono. (2009). Metode Penelitian Kuantitatif, Kualitatif dan R\&D. Bandung: Alfabeta. (2010). Statistika untuk Penelitian. Bandung: Alfabeta.

Suharsimi Arikunto. (2009). Dasar-dasar Evaluasi Pendidikan. Jakarta: PT Bumi Aksara. . (2010). Prosedur Penelitian suatu Pendekatan Praktik. Jakarta: PT Rineka Cipta.

Sumadi Suryabrata. (2006). Psikologi Pendidikan. Jakarta: PT RajaGrafindo Persada.

Sutrisno Hadi. (2004). Analisis Regresi. Yogyakarta: Andi Offset.

Syaiful Bahri Djamarah. (2005). Guru dan Anak Didik dalam Interaksi Edukatif. Jakarta: PT Rineka Cipta.

Wina Sanjaya. (2009). Strategi Pembelajaran Berorientasi Standar Proses Pendidikan. Jakarta: Kencana.

W.S. Winkel. (2009). Psikologi Pengajaran. Yogyakarta: Media Abadi.

Zaki Baridwan. (2004). Intermediate Accounting. Yogyakarta: BPFE. 